\title{
THE LITERARY FORM OF THE PRESCRIPT OF ANCIENT ROYAL LETTERS AND A HINT FOR ITS TRANSLATION: EZRA 4:17 AS CASE STUDY
}

Joohan Kim

Ancient Studies

Stellenbosch University

\begin{abstract}
Two English versions of the prescript of the letter embedded in Ezra 4:17, i.e. KJV and NIV, show variations in the translations. While KJV starts the letter with a greeting, NIV opens with the name of the recipient. From this difference, we should ask which translation most closely reflects the original intention of the author, who incorporated this royal letter into his work. Thus, by examining this generic feature (the prescript) of ancient royal (and official) letters and the technique of embedding them, this article attempts to determine which translation is preferable. This investigation is possible because the prescript pattern of ancient royal letters was very often consistent in the Mediterranean world at this time. In other words, the person at the highest social level (i.e. the king in the case of royal letters) is always placed first in the prescript, no matter whether he is the sender or the recipient. Besides this, ancient authors (including the author of Ezra) tended to adopt this convention when they embedded royal letters in their work. Taking these facts into account, this article suggests that the translation of the type of KJV reflects the original intention of the author of Ezra more exactly.
\end{abstract}

Key Words: Ancient Royal Letter, Letter Prescript, Ezra 4:17, Translation

\section{Introduction}

Recent translators of the Holy Scriptures have a tendency to preserve the original genre in translation (Zogbo and Wendland 2000:7). This approach acknowledges the importance of the genre in transferring the meaning of the original text. However, in the translation of the prescript (4:17) of a letter in Ezra 4:17-22, we encounter a translation problem when we try to take the genre of ancient royal letters into account. ${ }^{1}$ For example, two popular English versions, i.e. KJV and NIV, provide slightly different translations of the prescript in Ezra 4:17 as follows:

In Ezra there are five (embedded) letters, especially in the Aramaic text (4:8-6:16; 7:12-26). However, while translations of the prescripts of four of the five embedded letters (i.e. Ezra 4:11-16; 5:7b-17; 6:6-12; 7:12-26) are the same in form, the translations of the prescript of one letter (i.e. Ezra 4:17-22) show variations (cf. Fitzmyer 1974:205, n. 15). 


\begin{tabular}{|l|l|}
\hline KJV (cf. NASB) & NIV (cf. NRSV) \\
\hline Then sent the king an answer unto & The king sent this reply: To Rehum the \\
Rehum the chancellor, and to Shimshai & commanding officer, Shimshai the \\
the scribe, and to the rest of their & secretary and the rest of their \\
companions that dwell in Samaria, and & $\begin{array}{l}\text { associates living in Samaria and } \\
\text { elsewhere in Trans-Euphrates: } \\
\text { unto the rest beyond the river, Peace, } \\
\text { and at such a time (my emphasis). }\end{array}$ \\
\hline
\end{tabular}

In their translations of the prescript of this embedded letter KJV and NIV deal in different ways with the starting point of the prescript. KJV (like NASB) connects a prepositional

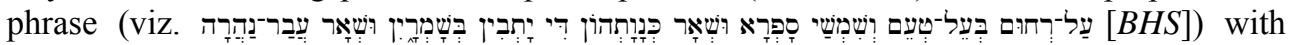
the main verb as an indirect object and so the prescript begins with the greeting without mentioning either the sender or the recipient. NIV (like [N]RSV) included this prepositional phrase as a part of the prescript and so the prescript begins with the name of the recipient. But at the point where the translation should reflect the meaning of the original text, which is often conveyed in a literary form, this difference between KJV and NIV, which seems to show diverse understandings of the prescript of ancient royal letter, should be examined and explained.

At this point we should look at the prescript form of ancient royal letters, because in this instance the problematic verse (i.e. Ezra 4:17) is the prescript of the royal letter that the king Artaxerxes sent to his subjects (cf. Ezra 4:7, 11). In addition, we should also look at the embedding technique adopted by the author of Ezra for the letters, because this author seems to have certain distinctive habits in incorporating such sources. But we also should remember that authors very often copied the original form of the source letter, because quoted letters were often considered to be authoritative, even though authors readily omitted or changed the prescripts and the subscripts. Furthermore, because both original letters and quoted letters were in most cases open to everyone who read relevant authors' work(s), the authors were expected not to fabricate letters. Thus, in order to deal with the differences between the two translations in this case, it is necessary to look at both the formal features of the prescript of ancient royal letters and the way that Ezra adapted the prescripts when he embedded royal letters in his work. Therefore, I shall first look at the conventional features of the prescript of ancient royal letters that were transmitted both as independent texts and in embedded form. And, taking into account the findings of previous studies, I will investigate the habit(s) of the author of Ezra in embedding letter materials in his work. Finally, in the light of these analyses, I shall suggest which translation between KJV and NIV reflects the intention of the author of Ezra most closely. This concluding suggestion will hint at the translation technique of the prescript of ancient royal letter.

\section{The Prescript of Ancient Royal Letters}

A prescript is the first part of a letter, which indicates addressor and addressee, and includes the salutation. Though the prescript is partly or wholly omitted in transmitted letters in literary works (and even in independent letters), most extant letters preserve the prescript in its full form. One striking fact about the prescript is that its structure is very often fixed according to letter type (White 1982:92; 1986). This is also true of the royal letter type (Welles 1933). I will deal with the prescripts of Aramaic and Greek royal letters that have been transmitted either as independent texts or in embedded form in literary works. 


\section{Prescript of Independently Transmitted Royal (and Official) Letters}

\section{Aramaic Letters $^{2}$}

Few Aramaic letters have been preserved, though numerous letters were composed from the $7^{\text {th }}$ century BCE up to the time of Bar Kokhbah (Dion 1981:59). So available sources of Aramaic letters are a few biblical texts such as Daniel and Ezra, and some non-biblical texts found both in Elephantine and Hermopolis West in Egypt as well as in Palestine (Fitzmyer 1974:209; Dion 1981:59-60). It is well known that the prescripts of Aramaic letters are quiet diverse. ${ }^{3}$ Fitzmyer (1974:211) describes 'five ways' for the order of the prescript in Aramaic letters: (1) 'To X, your servant/brother/son, (greeting)'; (2) 'To X, from Y, (greeting)'; (3) 'From X, to Y, (greeting)'; (4) 'X to Y, (greeting)'; and (5) 'To X, (greeting).' In his study Fitzmyer did not try to connect a specific formula with any specific letter type, so we cannot say anything more specific about the form of the prescript of Aramaic royal letters. Nevertheless, we need to devote attention to two examples in this study, i.e. the prescript of Ezra 7:12 and AdonL 1. Ezra 7:12 ${ }^{4}$ is a letter that a king (the highest position) sent to his servant (in a lower position), while AdonL $1^{5}$ is letter that a lower-ranking person sent to a king. These two prescripts are different in a number of aspects. Firstly, Ezra 7:12 is a royal letter in the precise sense, while AdonL 1 is not a royal letter but an official letter. Secondly, while Ezra 7:12 is an embedded letter in Ezra, AdonL 1 is an independent text. Finally, in terms of Fitzmyer's five categories for the prescripts of Aramaic letters, Ezra 7:12 belongs to the second category (viz. 'To X, from Y, [greeting]'), while AdonL 1 belongs to the fourth category (viz. 'X to Y, [greeting]'). Since the positions of the sender and the recipient are fully reversed in prescripts of these letters, we can say that the formulation of their prescripts is totally different. Nevertheless, these two examples are worthy of attention together, because both letters have one common feature: the two prescripts place the 'king' at the first position even though the 'king' is the sender in one instance and the recipient in the other. This phenomenon is noteworthy especially when we consider that other letter types, such as familiar letters, show flexibility in the order of the sender and the recipient in the prescript according to the epistolary situation (Dion 1981:6062; cf. White 1986). From this we can conclude that putting the 'king' at the first position in the prescript is a feature of Aramaic royal (and official) letters, regardless of whether the king is the sender or the recipient.

\section{Greek Letters}

In his study on Hellenistic royal letters Welles (1934:xxxviii) investigated "seventy-five texts, principally from the Seleucid and Attalid kingdoms, but also from the Asiatic dependencies of the Ptolemaic kings of Egypt and the minor kingdoms of Asia Minor." Of

2 In examining Aramaic letters it is quite reasonable to consider Hebrew letters as well. Nevertheless, I do not deal with them in this essay, because they do not provide any useful information for a study of the prescripts of the letters in Ezra. According to Pardee (1978:337), the order of 'superior-inferior' found in the addresses of non-biblical Hebrew letters does not indicate any fixed rule. If there is one, "it would appear that there was little constraint ca. 600 B.C. for the sender to identify himself (unless related to the recipient), but, when he did, his name preceded that of the recipient without regard for his social relationship to the recipient." The situation is similar for Bar Kokhbah's letters.

3 As opposed to the prescripts of Aramaic letters, those for Hebrew letters are uniform (Dion 1981:332). However, in terms of the pattern of the prescript, while the prescripts of Greek (papyrus) letters show variance according to each specific letter type, those of Aramaic letters do not (cf. White 1982:92).

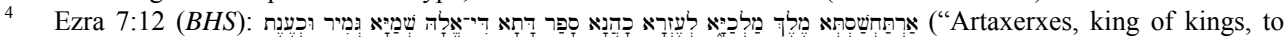
the priest Ezra, the scribe of the law of God of heaven: Peace. And now").

5 AdonL 1: אל מרא מלכן פרעה עבדך אדן [אשקלון]"To the lord of kings, the Pharaoh, your servant Adon, king of [Asheklon]"). 
these 75 letters, $46^{6}$ have preserved the prescript in the form of "the sender (either king or the superior) - the recipient (the inferior) - the greeting" where the king (or the superior) is

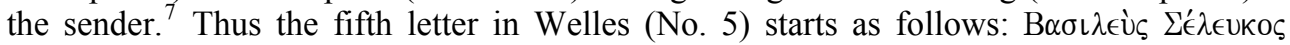

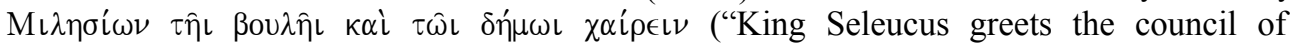
Miletus and her people" [my translation]). One limitation of Welles's examples is that his letters do not contain any instances where the king appears as the recipient. So we cannot say with confidence that the prescripts of all Greek royal letters follows the principle that the 'king' is placed at the first place, regardless of whether he is the sender or the recipient. However, we can suggest that this is the case with the following analogous explanation. White (1972) investigated the Greek official letter type, i.e. the (official) petition. After having analysed 71 official petitions, White (1972:13) concluded that the fixed form of the prescript of the petition is "some variation of 'To B-from A-'." White's conclusion provides a decisive indication of whether, in Greek royal letters, the king (i.e. the superior) takes the first position in the prescript, even though he is the recipient. In the prescripts of petitions, i.e. "To B-from A-," A means one who petitions (i.e. the sender) and B is the one who is petitioned (i.e. the recipient). Normally the one who is petitioned has the higher (social) position. This means that, in the official letter type, one who has a higher (social) position is placed at the first position in the prescript, even though he is the recipient. At this point we need to remember two things. First, the royal letter is a kind of official letter type and, second, the king has the highest authority in any case. From this fact we can suggest that in the royal letter the king will be placed at the first place even though he is the recipient.

\section{Prescript of Embedded Royal (and Official) Letters}

A number of embedded letters are found in ancient texts (cf. Rosenmeyer 2001; Parsons 2008:217-218). Ezra is such a case. However, before investigating embedded letters in Ezra and its author's technique of embedding them, I will first look at other embedded letters found in ancient Aramaic and Greek works. Although such a study would not provide any direct explanation of the embedded letters in Ezra, I expect that this will provide some common ground to explain the custom and technique of embedding letters in Ezra.

\section{Embedded Royal (and Official) Letters in the OT (Daniel)}

As Ezra is an OT text, it would be illuminating to examine other books from the OT. Except for four Aramaic letters in Ezra, there are another two Aramaic letters in the OT, i.e. Dan 3:31 and 6:26. Firstly, Dan 3:31 (NRSV 4:1) provides a good example of the prescript of an embedded royal letter (Hartman and Di Lella 1978:174; Pace 2008:121). Here we find that the author preserves the complete form of the prescript ("King Nebuchadnezzar to all

\footnotetext{
Nos. $2,4,5,6,7,9,10,11,12,13,14,15,18,22,23,25,31,31,33,34,35,36,38,39,41,43,45,<47>, 52$, $<54>, 56,<58,59>, 61,62,64,65,66,67,69,70,71,72,73,74,75$. Actually, if we had the perfect texts of the rest, the number would have increased.

7 Of the 46 letters, 42 begin with title "king + his proper name," but four letters (viz. nos. 47, 54, 58, 59) start only with 'proper name', in which case we cannot assert the addressor is a king or simply a higher officer than

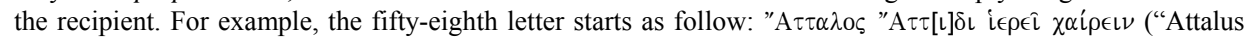
greets Att[i]s a priest" [my translation]). But an intertextual study of other letters reveals Attalus' identity as a

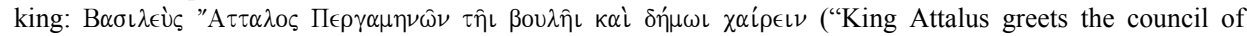
Pergamon and her people" [my translation]") (no. 67). This phenomenon is confirmed with other example such as P.Lond. 4.1912 [=CPJud II 153] (White 1986).
} 
peoples, nations, and languages that live throughout the earth: May you have abundant prosperity" [NRSV]). ${ }^{8}$ This is an example not only of the prescript of a royal letter that is fully preserved in its embedded form, but also one that shows the order of the prescript of the Aramaic royal letter follows the sequence of "the sender (either the king or the superior) - the recipient (the inferior) - the greeting" (Hartman and Di Lella 1978:175; Collins 1993:221). Secondly, Dan 6:26 (NRSV 6:25) ${ }^{9}$ has almost similar words to the prescript in Dan 3:31 (NRSV 4:1). However, its nature and function are different from those of Dan $3: 31$, as suggested by the position of the main verb כִּח . Because of the position of the main

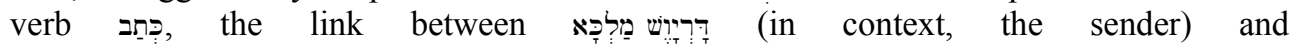

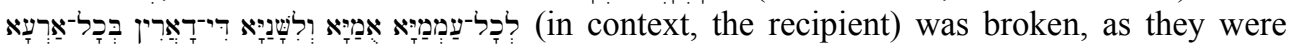

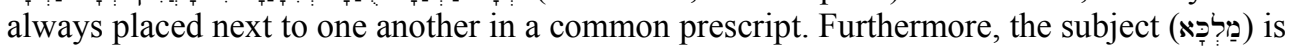
placed before the verb (כפב). Of course, this word order is a common sequence in Aramaic verbal sentences (Rosenthal 1986:56 [§183]; Greenspahn 1999:124). Nevertheless, the

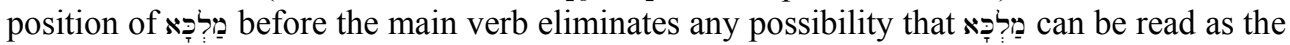
sender of the letter. Therefore, with reference to the prescript of Dan 6:26, we can suggest that the author of Daniel reduced the prescript to a short form of (May you have abundant prosperity!"). In this sense, NRSV 4:1 ("Then King Darius wrote to all people and nations of every language throughout the whole world: 'May you have abundant prosperity!"”) provides a good example of how carefully the author embedded the royal letter material into his work. Furthermore, as Fitzmyer (1974:211) does not provide a prescript pattern that begins with the greeting alone, we can suggest that the prescript of Dan 6:26 is an adaptation by the author of Daniel.

\section{Embedded Royal (and Official) Letters in LXX (1 Maccabees)}

There are nine instances of embedded royal (or official) letters in LXX 1 Maccabees $(10: 18,26 ; 11: 30,32 ; 12: 6 ; 13: 36 ; 14: 20 ; 15: 2,16)$. These nine letters have all the parts of the prescript and all of them preserve the normal sequence of the prescript of the royal letter type: "the sender (either the king or the superior) - the recipient (the inferior) - the greeting." For example, 1 Macc 15:2 ("And their contents were like this: 'King Antiochus to Simon the great priest and ethnarch and the nation of the Judeans, greeting" $[\text { [NETS] })^{10}$ illustrates well how the author of 1 Maccabees embedded the royal letter material into his work. Here, before introducing this letter, the author used an introductory formula, i.e. $\kappa \alpha i$

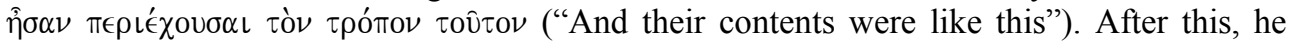
presented the royal letter with the full prescript. The author's adoption of the introductory

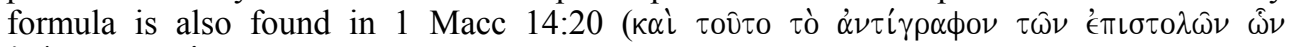
$\dot{\alpha} \pi \epsilon^{\prime} \sigma \tau \epsilon \iota \lambda \alpha \nu$ oi $\Sigma \pi \alpha \rho \tau \iota \hat{\alpha} \tau \alpha L \ldots$..), which also precedes the whole prescript (cf. Ezra 4:11a). Thus we can say that the author of 1 Maccabees was accustomed to using the introductory formula to embed the letter material. Besides royal letters, there are a few official letters in 1 Maccabees (e.g. 12:6;14:20;15:16). The difference from the prescript of the royal letter is that in official letters the order of "the sender - the recipient" is dependent on the (political and social) relationship between the sender and the recipient (e.g. 15:16). However, where the social relationship between the sender and the recipient is equal (or

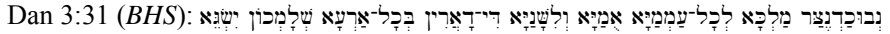

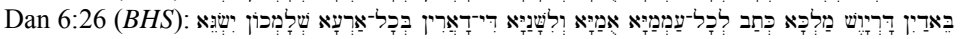

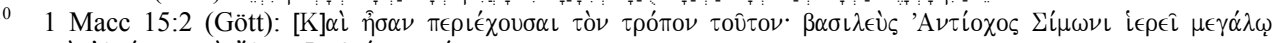

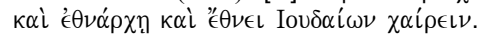


ambiguous), there seemed to be flexibility in the order in the prescript (e.g. 12:6; 14:20). ${ }^{11}$ In any event, all examples keep all the parts of the prescript. In summary, the author of 1 Maccabees tended to keep the whole prescript as it is (i.e. "the sender [either the king or the superior] - the recipient [the inferior] - the greeting") and he also used the introductory formula as an embedding device, as needed.

\section{Embedded Royal (and Official) Letters in NT (Acts)}

In NT we can find a number of independently transmitted letters (e.g. Paul's letters and others) and a few embedded letters (e.g. Acts 15:23; 23:26-30; Rev 2-3). The letter in Acts 15:23-29 has been considered the first official Christian letter (cf. Aune 1987:128; Stirewalt 2003:40) and the letter in Acts 23:26-30 is a typical Roman official letter (Witherington 1998:467-78, 699; Klauck 2006:419-34). In the prescript of both embedded letters in early Christian work we also find the same pattern of "the sender (either the king or the superior) - the recipient (the inferior) - the greeting" in full form. ${ }^{12}$ Furthermore, in both cases (Acts

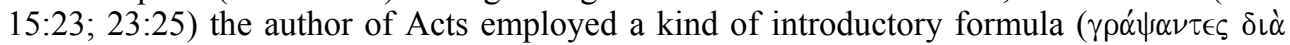
$\chi \in \iota \rho \grave{\varsigma} \varsigma \alpha \dot{\tau} \tau \hat{\omega} \nu)$ just as other authors sometimes did (e.g. Dan 6:26; 1 Macc 14:20; 15:2).

\section{Embedded Royal (and Official) Letters in Josephus and Eusebius}

Among extra-biblical texts we can find good instances of embedded (royal or official) letters in Josephus (37/38-ca.100 CE) and Eusebius of Caesarea (ca. 265-340 CE). But for want for space, I choose only one example from both authors respectively. Firstly, in Ant. 13.125-126, Josephus quotes a royal letter that Demetrius, a king, sent to his brother Jonathan ("of which the contents were as follows: 'King Demetrius to his brother Jonathan and to the Jewish nation, greeting"" [Marcus, LCL]). ${ }^{13}$ From this passage we can see that

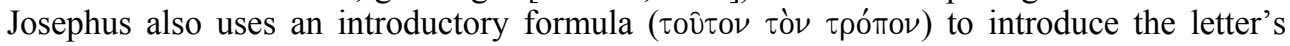
source and he keeps the whole of the prescript of the royal letter according to a customary order. Secondly, Eusebius of Caesarea also writes the prescript in the same way as Josephus. Thus, for example, in his Hist. eccl. 4.13.1 we can find a prescript of a royal letter from the emperor Antoninus to the council of Asia (ca. $161 \mathrm{CE}$ ): "The Emperor Caesar Marcus Aurelius Antoninus Augustus Armenicus, Pontifex Maximus, Tribune for the fifteenth time, Consul for the third time, to the Council of Asia, greeting" (Lake, LCL). ${ }^{14}$ As a royal letter, this prescript also follows a typical sequence. But here Eusebius did not use any introductory formula. But he nevertheless kept the prescript of the royal letter in embedding it into his work.

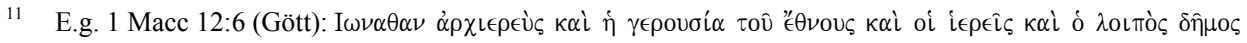

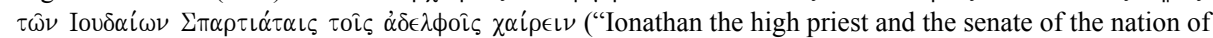
the priests and remaining citizenry of the Judeans to their brothers the Spartans, greeting" [NETS]); 14:20

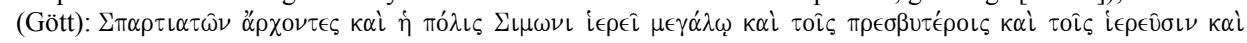

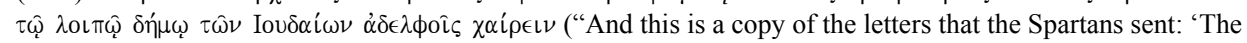
rulers and the city of the Spartans to Simon the great priest and the elders and the priests and the remaining citizenry of the Judeans, our brothers, greeting"” [NETS]).

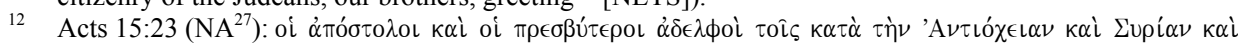

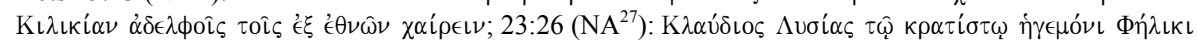
$\chi \alpha i \rho \in\llcorner\nu$.

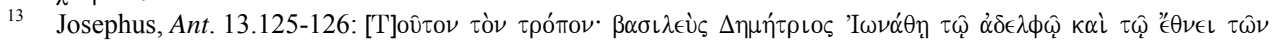

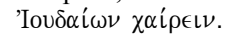

14 Eusebius, Hist. eccl. 4.13.1: Аủ

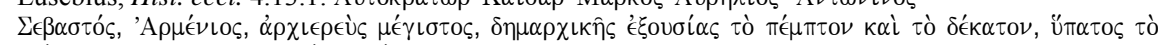

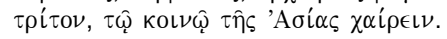




\section{Summary}

Throughout these analyses we have reached two tentative conclusions concerning the prescripts of the ancient royal (and official) letters, which are decisive for the discussion below. Firstly, the prescripts of the royal letter, no matter in what languages they were composed, show the same pattern in both independently transmitted letters (2.1) and embedded letters (of course, only when an author kept the whole prescript) (2.2), i.e. "the sender (either the king or the superior) - the recipient (the inferior) - the greeting" or "the recipient (either the king or the superior) - the sender (the inferior) - the greeting." Secondly, when an author used royal (and official) letters as sources, the author tended either to write the entire prescript or to omit some part of the prescript, i.e. the sender and the recipient, except the greeting.

\section{Prescripts of Embedded Letters in Ezra and Translation of the Prescript of Ezra 4:17}

\section{Prescripts of Embedded Letters in Ezra (excluding 4:17)}

Fitzmyer (1974:220) points out that letters "in Ezra supply the closest parallels to the extrabiblical material." Fitzmyer's investigation offers some grounds to compare the letters in Ezra and other texts. Thus, in this section I will analyse the prescripts of five letters that appear in Ezra 4-7 and compare them with the contents of the letter discussed above. In doing so, I expect to establish a few guidelines for translating the prescript of the letter in Ezra 4:17-22. As above, the author of Ezra embedded five letters into his work, i.e. Ezra 4:11-16, 4:17-22, 5:7b-17, 6:6-12 and 7:12-26. These five letters can be classified into three groups according to the degree to which the typical form of the prescript has been preserved, i.e. the letter group that perfectly preserved the whole prescript (Group 1 [e.g. Ezra 7:12]); the letter group that adapted the prescript in the author's style (Group 2 [e.g. Ezra 4:11, [17]; 5:7]); and the letter group that omitted the entire prescript (Group 3 [e.g. Ezra 6:6]).

\section{Group 1: Ezra 7:12}

The passage in Ezra 7:12 keeps all the parts of the prescript of a royal letter ("Artaxerxes, king of kings, to the priest Ezra, the scribe of the law of the God of heaven: Peace. And now" [NRSV]). ${ }^{15}$ This follows the customary pattern of the prescript of a royal letter, i.e. "the sender (either the king or the superior) - the recipient (the inferior) - the greeting" (cf. Dan 3:31; 1 Macc 11:30, 32; 12:6; 13:36; Eusebius, Hist. eccl. 4.13.1). This provides an example that Ezra has adopted the traditional way in preserving the prescript of the royal letter in embedding the source letter into his work.

Group 2: Ezra 4:11; 5:7

Firstly, the passage in Ezra 4:11 ("This is the copy of the letter that they sent unto him, even unto Artaxerxes the king; Thy servants the men on this side the river, and at such a time" $[\mathrm{KJV}])^{16}$ shows a common pattern of the prescript of royal letters (i.e. "the recipient [either the king or the superior] - the sender [the inferior] - the greeting"; cf. Ezra 7:12) in the full prescript except the greeting. The omission of the greeting cannot be explained because there are no other samples. We only find various attempts to solve this problem.

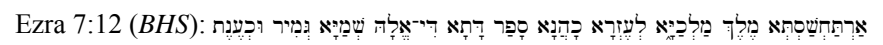

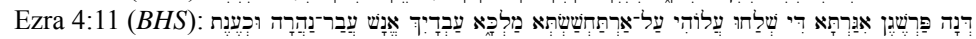


For example, NRSV and Vulgate inserted the greeting, i.e. 'send greeting' or salutem,

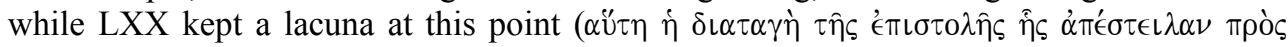

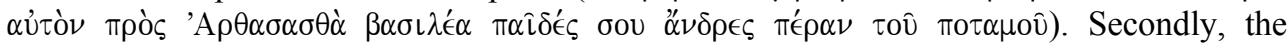
passage in Ezra 5:7(“[T]hey sent him a report, in which was written as follows: 'To Darius the king, all peace!"” $[\mathrm{NRSV}])^{17}$ raises a more serious problem. In many English versions this prescript omits mention only of the sender. This verse has been translated either as "Unto Darius the king, all peace" (KJV) or as "To Darius the king, all peace[!]" (NASB and NRSV) or "To King Darius: Cordial greetings" (NIV) or "Greetings to King Darius" (NLT). At first glance, these translations seem not only to be faithful to the original text, but also to reflect a pattern of the prescript of Aramaic letters. Furthermore, we have a prescript formula of "To X, [greeting]" among the prescripts of Aramaic letters (Fitzmyer 1974:211). ${ }^{18}$ However, the core of the problem is that, compared to the prescripts of later Aramaic letters in Hellenistic and Roman times, the preposition ? was rarely used as a marker of the recipient in the prescript of Old and Imperial Aramaic letters. Instead, either ֵַ was wenerally employed (Schwiderski 2000:102-111, 247-248). ${ }^{19}$ As is commonly known, the Aramaic of Ezra belongs to 'Imperial Aramaic' (Greenspahn 1999:6; Rosenthal 1968:6). Thus, based on Schwiderski's conclusion, we cannot consider the preposition Ezra 5:7 as a marker of the recipient in the prescript. Furthermore, in this context the

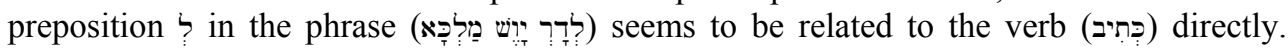
Considering these facts, we can conclude the prepositional phrase to be an indirect object of the verb פְּיב. Therefore we may consider the prescript of Ezra 5:7 as a reduced prescript as in the case of the prescript of Dan 6:26. Furthermore, the author of Ezra used an introductory formula here (cf. 4:11) which used to be found in other embedded royal letters (e.g. Dan 6:26; 1 Macc 14:20; 15:2; Acts 15:23; Josephus, Ant. 13.125).

\section{Group 3: Ezra 6:6}

The passage in Ezra 6:6 provides an example of where Ezra has omitted the entire prescript. Different from the letters of the above group with adapted prescripts (3.1.2), this group

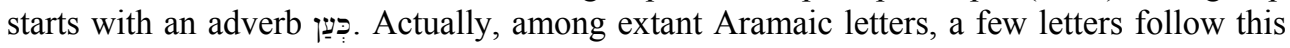
pattern (Schwiderski 2000:111-112; cf. Fitzmyer 1974:205, n. 15). This example also shows that the author of Ezra adapted his letter source for his work, written in the Imperial Aramaic letter tradition.

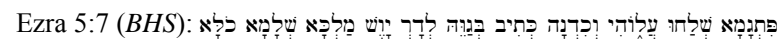

18 Because there seems to be no extant pattern of a prescript that begins with the greeting alone according to Fitzmyer's list (1974:211), the translation of "To Darius the king, all peace[!]" (NRSV) is preferred to any example that begins with the greeting (actually, there are no versions that are translated in this way). However, what we should remember is that Fitzmyer, firstly, does not say anything about independently transmitted letters here, and the author of Ezra adapted his letter sources to embed them into his work, as other authors often did.

19 At this point the examples of the preposition in Ezra and Daniel (Ezra 7:12; Dan 3:31) that were used as the marker of the recipient raises a problem for the dating of these books. However, recently Williams questioned Schwiderski's conclusion based on JA Lund's study (Williamson 2008:59-60). Cf. Fitzmyer (1974:213), who insists that the preposition ? was used as the marker of the recipient. However, his instances consist of the later Aramaic letters such as 5/6 Hev 1:1 and Gamaliel 1,2,3, etc., though he places Ezra 5:7; 7:12 and Dan 3:31 (on the date of these letters, see Fitzmyer 1981:40-43, especially, 43; on the Aramaic in Daniel, see Greenspahn 1999:6). Thus, the understanding of the preposition ? can be considered a problem of interpretation, not of letter form. 


\section{Prescript of Ezra 4:17 and Suggestion for Translation}

The prescript of Ezra 4:17 can be classified into either the first group (3.1.1) or the second group (3.1.2) according to how we understand the nominal phrase,

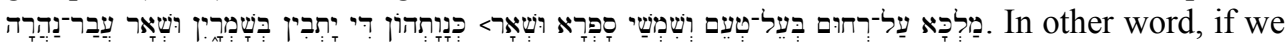
understand this phrase to belong to the prescript (3.1.1), we can say that the author kept the

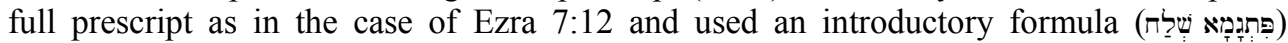
according to his custom (e.g. Ezra 4:11;5:7). On the other hand, if we understand this

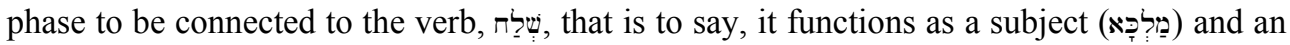

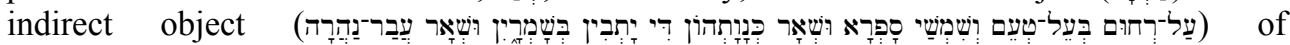
שִ respectively (3.1.3), we can say that the author adapted the first two component of the prescript for the story line and reduced them to the 'Greeting' just as he and other authors often did (e.g. 5:7; cf. Dan 6:26). Therefore we can say that there is no problem if we translate on the basis of this understanding (cf. KJV and NASB).

However, the problem arises from the fact that many English versions open the prescript with the prepositional phrase:

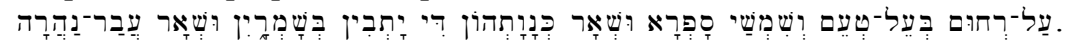

For example, NRSV translates this verse as follows: "The king sent an answer: 'To Rehum the royal deputy and Shimshai the scribe and the rest of their associates who live in Samaria and in the rest of the province Beyond the River, greeting. And now' " (my emphasis). Actually, because the quotation marks in NRSV indicate direct speech and the version tried to preserve a literary form as in poetry, the 'To Rehum...' is surely understood as direct speech that is quoted from the royal letter (Bruce 1978:190; Zogbo and Wendland 2000:7). In this regard, we can say that this is also a reduced form of the prescript with an introductory formula as in the case of the second group (3.1.2). Furthermore, we find some variance among prescript patterns of Aramaic letters, i.e. 'To X (greeting)' (Fitzmyer 1974:211), which seems to support this translation. Furthermore, in this context the noun

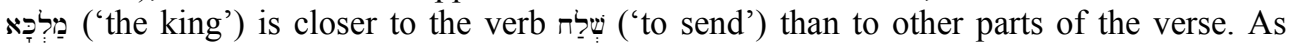
Schwiderski (2000:357) points out, it is normally accepted that whenever a 'king' as the 'sender' is placed at the first place of the prescript, the proper name should always appear with the title 'king' (e.g. Ezra 7:12; Dan 3:31; 1 Macc 15:2; Josephus, Ant. 13.126; Eusebius, Hist. eccl. 4.13.1). Nevertheless, this NRSV translation (and similar translations) still represents a problem. Firstly, Fitzmyer's study was limited to the prescript of independently transmitted letters and did not include embedded letters. Thus, we cannot assert that his study offers any ground for the NRSV translation. Moreover, we may remember that there is no example of the prescript of royal letter beginning with the inferior, no matter whether the inferior is the sender or the recipient. This fact applies to the prescript of embedded royal letters too. Therefore, we can see that, in embedding royal letters, the author chose a way either of preserving the full prescript or of omitting it entirely (except the greeting sometimes). Thus, this indicates that the translation of NRSV does not faithfully reflect the custom of embedding the prescript of a royal letter. Based on the above discussion, we can conclude that the prescript in Ezra 4:17 begins with just as in the case of Ezra 5:7.

\section{Conclusion}

In this brief essay I dealt with a translation issue related to the prescript of the embedded royal letter in Ezra 4:7 from the perspectives both of the prescript formula and of the embedding technique for ancient royal letters. Firstly, I surveyed the prescript pattern of independently transmitted royal letters in section 2.1. In this way I was able to show that 
the 'king' (or the superior) is placed at the first position of the prescript, no matter whether he is the sender or the recipient. This is the most important feature of the prescript of the ancient royal letter. However, the translation issue arose from a fact that our text (Ezra 4:17) is an embedded letter. Actually, many embedded letters show different features from independently transmitted letters, because they were used as sources in literary works. I therefore investigated how ancient royal letters were embedded in literary works on the basis of a few examples from Daniel in the OT, 1 Maccabees in LXX, Acts in NT, Josephus' Jewish Antiquities (Ant.), Eusebius' Church History (Hist. eccl.) (2.2) and from Ezra in the OT (3.1). Through analyses of these examples I could tentatively conclude that the following are features of the prescript of an embedded royal letter: (i) when it preserves both the sender and the recipient, the sequence of the prescript is the same as that of independently transmitted royal letters; (ii) sometimes only the king's name appears with the greeting, no matter whether he is the sender or the recipient; but (iii) when the king's name is omitted, only the greeting appears without mention of the inferior, no matter whether he is the sender or the recipient. Based on these analyses in section 3.2, I dealt with the translation issue of the prescript in Ezra 4:17 as an example and concluded as follows: at least in terms of literary form, the translation represented by KJV (or NASB) is closer to author's intention than the one that is represented by NIV (and NRSV). This is both (i) because the translation of NIV did not take into account the features of the prescript of ancient royal letters and (ii) because the suggestion of the translators of NIV that the phrase may be understood as referring to the sender and the recipient of the prescript respectively is not persuasive on the basis of the syntax of the phrase.

BHS Biblica Hebraeca Stuttgartensia

Gött The Göttingen Septuagint

KJV King James Version

LCL Loeb Classical Library

LXX Septuagint

NETS Pietersma, A \& Wright, B 2007. A New English Translation of Septuagint. Oxford: Oxford University Press.

NASB New American Standard Bible

$\mathrm{NA}^{27} \quad$ Novum Testamentum Graece, Nestle-Aland, 27th edition.

NIV New International Version

NLT New Living Translation

NT New Testament

(N)RSV (New) Revised Standard Version

OT Old Testament

\section{BIBLIOGRAPHY}

Aune, DE 1987. The New Testament in Its Literary Environment. Philadelphia: The Westminster Press.

Bruce, FF 1978. History of the Bible in English from the Earliest Versions.

New York: Oxford University Press.

Collins, JJ 1993. Daniel: A Commentary on the Daniel. Minneapolis: Fortress Press. 
Dion, PE 1981. The Aramaic 'Family Letter' and Related Epistolary Forms in Other Oriental Languages and in Hellenistic Greek. Semeia 22:59-76.

Eusebius 1953. The Ecclesiastical History with an English Translation. Translated by

K Lake. 2 vols. Vol.1, LCL. London: William Heinemann LTD.

Fitzmyer, JA 1974. Some Notes on Aramaic Epistolography. JBL 93:201-225.

Fitzmyer, JA 1981. Aramaic Epistolography. Semeia 22:25-41.

Greenspahn, FE 1999. An Introduction to Aramaic. Atlanta, Georgia: Scholars Press.

Hartman, LF, and AA Di Lella. 1978. The Book of Daniel: A New Translation with Introduction and Commentary. New York/London/Toronto/Sydney/Auckland: Doubleday

Josephus 1943. Josephus with an English Translation. Translated by P Marcus. 9 vols. Vol. 7, LCL. London: William Heinemann LTD.

Klauck, H-J 2006. Ancient Letters and the New Testament: A Guide to Context and Exegesis. Waco, Texas: Baylor University Press.

Lindenberger, JM 1994. Ancient Aramaic and Hebrew Letters. Atlanta, Georgia: Scholars Press.

Pace, SH 2008. Smyth \& Helwys Bible Commentary: Daniel. Macon, Georgia: Smyth \& Helwys Publish.

Pardee, D 1978. An Overview of Ancient Hebrew Epistolography. JBL 97(3):321-46.

Parsons, MC 2008. Acts. Grand Rapids, Michigan: Baker Academic.

Rosenmeyer, PA 2001. Ancient Epistolary Fictions: The Letter in Greek Literature. Cambridge: Cambridge University Press.

Rosenthal, F 1968. A Grammar of Biblical Aramaic. Wiesbaden: Otto Harrassowitz.

Schwiderski, D 2000. Handbuch des nordwestsemitischen Briefformulars: Ein Beitrag zur Echtheitsfrage der aramäischen Briefe des Esrabuches. Berlin/New York:

Walter de Gruyter.

Stirewalt, ML Jr. 2003. Paul, the Letter Writer. Grand Rapid, Cambridge:

William B Eerdmans Publishing Company.

Welles, BC 1933. Royal Correspondence in the Hellenistic Period: A Study in Greek Epistolography. New Haven: Yale University Press.

White, JL 1972. The Form and Structure of the Official Petition. Missoula, Montana: Scholars Press.

White, JL 1982. The Greek Documentary Letter Tradition Third Century BCE to Third Century CE Semeia 22(1):89-106

White, JL 1986. Light from Ancient Letters. Philadelphia: Fortress Press.

Williamson, HGM. 2008. The Aramaic Documents in Ezra Revisited. JThS 59(1):41-62.

Witherington III, B 1998. The Acts of the Apostles: A Socio-Rhetorical Commentary. Grand Rapids, Michigan/Cambridge, UK: William B Eerdmans Publishing Company.

Zogbo, L, \& ER Wendland 2000. Hebrew Poetry in the Bible: A Guide for Understanding and for Translating. New York: United Bible Society. 